\title{
Justification of the method of determination of the border overburden ratio
}

\author{
Serhii Joukov ${ }^{1}$, Serhii Lutsenko ${ }^{1}$, Yulian Hryhoriev ${ }^{1, *}$, Maxim Martyniuk ${ }^{2}$, and Volodymyr Peregudov ${ }^{3}$ \\ ${ }^{1}$ Kryvyi Rih National University, Mining and Metallurgical Faculty, 11 Vitalii Matusevuch Str., Kryvyi Rih, 50027, Ukraine \\ ${ }^{2}$ SOUTH Mining and Processing Plant, Technical department, Kryvyi Rih, 50026, Ukraine \\ ${ }^{3}$ SDI “Krivbassproekt”, 40 Poshtoviy Ave., Kriviy Rih, 50000, Ukraine
}

\begin{abstract}
The economic efficiency of the enterprise and the length of its operation, the full utilization of mineral reserves and the total cost of operation depend on the selected depth and boundaries of opencast mining. In such conditions of the deposits' development it is necessary to evaluate the capabilities of the raw material base for the further development of the mining enterprise. The basis for determining of the border overburden ratio is on the condition that the price of manufactured marketable output of the designed enterprise should not exceed the price of the same marketable output in the world market. The realization of this condition is achieved analytically. This takes into account the impact of the rate of return on the final depth of the designed open pit. A new method of determining of the border overburden ratio is developed, which ensures the competitiveness of iron ore concentrate in the world market. The value of the border overburden ratio is developed for the Pershotravnevij open pit of the Northern mining and processing plant, depending on the situation of the iron-containing products' prices, which ensures the competitiveness of marketable iron-ore output in the domestic and world markets.
\end{abstract}

\section{Introduction}

The economic efficiency of the enterprise and the operation period, the full utilization of mineral reserves and the total cost of operation depend on the selected depth and boundaries of the opencast mining.

Nowadays, in the development of steeply falling iron ore deposits, their working contours on the surface have reached design marks on the most open pits. Mining development occurs only when they are lowered. In such conditions of the deposit development it is necessary to evaluate the capabilities of the raw material base for the further development of the mining enterprise.

When choosing opencast mining alternatives, their main parameters - open pit boundaries, mining mode and ore productivity - are assessed by economic indicators. These indicators are: profit from sales of saleable output; production costs of the saleable output; profitability, etc.

As practice shows, the depth and position of the final boundaries of the most large open pits as the mineral deposits are worked out are repeatedly revised and adjusted. However, it is imperative to determine the final boundaries of the open pit mining in which the development of open pit deposits will be effective. There is a concern about the designing a new enterprise, when similar mining companies are already operating.

Recent applied and scientific studies on this issue clearly indicate the need to re-evaluate the final boundaries of Ukraine's open pits [1-3]. The development in the approved by existing designs boundaries can lead to the rapid depreciation of the loading faces of the open pits on the final designed boundaries in the near future. And this will entail a significant increase in the cost of the opencast mining due to the reactivation of non-working faces, if the open-pit boundary will be redefined in future.

At present, there are a lot of methods in the theory and practice of design to determine the border overburden ratio and open-pit boundaries that develop steep-dipping banks. Today, the open pit boundaries are determined on the basis of a comparison of one of the overburden ratio of the designed open pit with the border overburden ratio. At the same time, to determine the border overburden ratio, economic indicators of the cost of ore underground mining method or the wholesale price of the mineral are most often used. However, in the world market of commodity iron ore products the only indicator of its competitiveness is price. Production costs and profitability are commercial secret. Therefore, the main condition for a comparative assessment of the operational efficiency of mining and processing plant in the world market is to compare the price of marketable products with the price of the same marketable products in the world market.

\section{Object and methods of research}

A great number of scientists were engaged in the questions of determining the open pit boundaries. The largest contribution [4-11] in the theory of designing the boundaries of open-cast mining is owned by

\footnotetext{
* Corresponding author: juliangrig@gmail.com
} 
A. I. Arsentyev, V. V. Rzhevskij, B. P. Yumatov, V. S Hohryakov, V. G. Bliznyukov, A. K. Polishuk, Yu. I. Anistratov.

Designers and scientists use the main criteria for evaluating [9-10] the boundaries of effective mining of open-pit deposits use the cut-off (economically viable) overburden ratio as the main criterion, which is the maximum permissible overburden ratio, according to which open-pit mining in these specific conditions economically feasible.

There are several well-known principles to justify the depth of the open pits, based on the comparison of one of the overburden ratio (average, initial, contour, current, mid-operational) or the sum of these coefficients with the cut-off (economically feasible) overburden ratio.

The economic basis of all calculation principles for determining the boundaries of the open pits is to compare the possible cost of ore mining with the expected over the designed open pit [12], and the cut-off overburden ratio of the overburden is calculated by the technical and economic indicators achieved at the mining enterprises at the time of design.

In this case, to determine the cut-off overburden ratio, the most commonly used economic indicators of the cost of ore mining by underground method or the wholesale price of minerals.

However, it should be understood that comparing the cost of open and underground mining is not correct due to the different production volumes; the open pit productivity is much higher than the productivity of mines, which to a different extent covers the needs of the market. In addition, the cost of mining by underground method remains equally high throughout all the service life, while the open pit reaches a production cost peak in only one of the operating periods at which the surface boundaries reach the final pit.

Recently, studies have been conducted on the determination of prospective mining boundaries of the open pits: the Scientific and Research Mining Institute (SRMI) [1, 13]; The Academy of Mining Sciences of Ukraine [2] and Kryvyi Rih National University (KNU) [3]. The determination of the cut-off overburden ratio was performed by these institutes on the basis of comparison of indicators of work of the investigated enterprise with indicators of enterprises with the underground method of mining, as well as with indicators of similar mining and processing plants. The price of the marketable products (concentrate), which depends on its quality, has always determined the boundaries of opencast mining. However, at different mining enterprises, marketable products of the same quality may have different selling prices [14], which in turn may make an error in determining the final boundaries of the open pits. Therefore, in the paper [15] it was proved contractual factors influence on the price of commodity products, which makes inaccurate application of existing methods for determining the final open pit boundaries.

However, the existing methods of determining the cutoff overburden ratio [16-18] do not take into account the competitiveness of the iron ore products of the designed enterprise in the world market.
At present, the strategic assessment of the interaction of the company with the external environment we must first take into account the qualitative and quantitative impact of competitors and demand on pricing [19], and, accordingly, the profit of the enterprise [20]. With different levels of the competitive environment and the supply-demand relationship, different options for choosing mining company strategy and, accordingly, a suitable methodology for selecting the final open pit outline.

Therefore, the goal was to develop a method of determining the cut off overburden ratio, which will allow while the formation of the price for iron ore products on the world market to determine the boundaries of the open pit, that ensures the competitiveness of mining and processing plant.

To achieve this goal, a complex research method was used in the work, which includes theoretical and instrumental methods: analysis and theoretical generalization of enterprises reports, scientific and technical publications and other information sources in the field of determining the boundaries of careers in substantiating the problem and task of research; system analysis in researching career indicators; analytical, graphical and graphoanalytical methods of the research of technological and economic interconnections of the mining mode and the productivity by minerals in determining the boundaries of the career; economic and mathematical modeling of career options.

\section{Results}

The only indicator of the competitiveness of the marketable iron ore products is its price. Therefore, the main condition for a comparative assessment of the designed mining and processing plant in the world market is to compare the price of finished product with the price of the same product in the world market. Hence, the basis of the determination of the cut-off overburden ratio will be the condition that the price of the finished product of the designed enterprise does not exceed the prices of the same marketable products in the world market, which is represented by inequality:

$$
P_{c}^{d} \leq P_{c}^{W}
$$

where $P_{c}^{d}$ - the price of the concentrate of the designed mining and processing plant, $\mathrm{UAH} / \mathrm{t} ; P_{c}^{W}$ the price of the concentrate in the world market, UAH/t.

At any mining enterprise we plan the profit margin, which is expressed by the final sum of production profitability of the enterprise. Therefore, the price of the concentrate of the designed mining and processing plant can be represented as:

$$
P_{c}^{d}=C_{c}^{d} \cdot(1+\psi), \mathrm{UAH} / \mathrm{t}
$$

where $C_{c}^{d}$ - the prime cost of the concentrate of the designed mining and processing plant, $\mathrm{UAH} / \mathrm{t} ; \psi-$ target profit marginy, parts un. 
The cost of production of the concentrate of the designed mining and processing plant will be represented by the expression:

$$
C_{c}^{d}=\frac{a_{m}^{d}+a_{c}^{d}+b^{d} \cdot n}{\gamma_{c}^{d}}, \mathrm{UAH} / \mathrm{t},
$$

where $a_{m}^{d}$ - the cost of ore mining without the expense of the overburden in the designed open pit, $\mathrm{UAH} / \mathrm{t} ; a_{c}^{d}$ - the cost of the ore conversion to the concentrate at the designed mining and processing plant, $\mathrm{UAH} / \mathrm{t} ; b^{d}-$ the cost of the overburden in the designed open pit, $\mathrm{UAH} / \mathrm{m}^{3}$; $n$ - the overburden ration in the designed open pit, $\mathrm{m}^{3} / \mathrm{t}$; $\gamma_{c}^{d}$ - concentrate output from one ton of ore to the designed mining and processing plant, parts un.

On this basis, the expression of determination of the concentrate price of the designed mining and processing plant (2) will take the following form:

$$
P_{c}^{d}=\frac{a_{m}^{d}+a_{c}^{d}+b^{d} \cdot n}{\gamma_{c}^{d}} \cdot(1+\psi), \mathrm{UAH} / \mathrm{t} .
$$

The price of concentrate, which is on the world market, depends on the content of iron. Therefore, the price of the concentrate of the designed mining and processing plant should be brought (in terms of the content of iron) to the price of the base enterprise (the price of concentrate and its iron content in the world market). Then the expression will look like this [1]:

$$
P_{c}^{\prime d}=P_{c}^{W} \cdot \frac{\beta^{d}}{\beta^{W}}
$$

where $P_{c}^{\prime d}$ - the present value of the concentrate of the designed mining and processing plant at the price of concentrate and the content of iron in it on the world market, $\mathrm{UAH} / \mathrm{t} ; \beta^{W}$ i $\beta^{d}$-iron content in the concentrate in the world market and designed mining and processing plant, accordingly, parts un.

On this basis, the price of the designed concentrate will be defined as:

$$
P_{c}^{\prime d}=\frac{\beta^{d} \cdot\left(a_{m}^{d}+a_{c}^{d}+b^{d} \cdot n\right)}{\gamma_{c}^{d} \cdot \beta^{W}} \cdot(1+\psi), \mathrm{UAH} / \mathrm{t} .
$$

Based on formula (2), the cost of concentrate on the designed mining and processing plant as an indicator of competitiveness, depends on the planned profit and volume of overburden works. Other indicators are determined by the level of technology and technology of ore and dead rocks mining $\left(a_{m}^{d}\right.$ i $\left.b^{d}\right)$, achieved at the enterprise, indicators of technology for ore conversion to concentrate and quality of ore $\left(a_{c}^{d}, \gamma_{c}^{d}, \beta^{d}\right)$.

These indicators in determining the competitiveness of similar companies, can be taken constant, as they do not change for a long time, and if they change, then at almost the same rate. For example, let's consider the graphs of the change in the price of concentrate of the North mining and processing plant from the current overburden ratio with different iron content in concentrate in the world market (Fig. 1, 2).

From the presented pictures we can see that while maintaining the profitability of the enterprise at the same level, with the increase of the overburden ratio, the price of production should increase. With a constant overburden ratio, increasing profitability is possible only with the increase of the price of products.

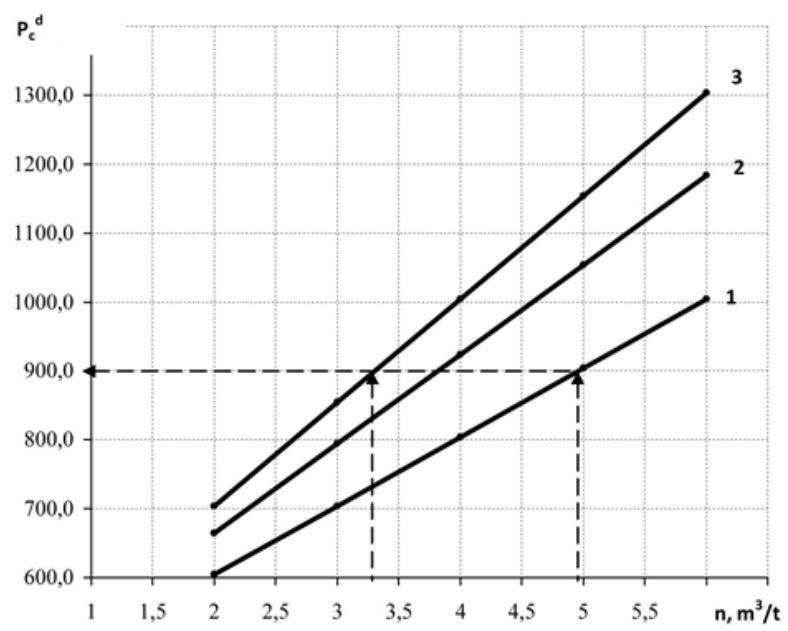

Fig. 1. Changes in the price of the concentrate of the Northern mining and processing plant, depending on the current overburden ratio when the iron content of the concentrate in the world market $65 \%$ : 1 - at the rate of profit $\psi=0 \% ; 2-$ when $\psi=30 ; 3-$ when $\psi=50$.

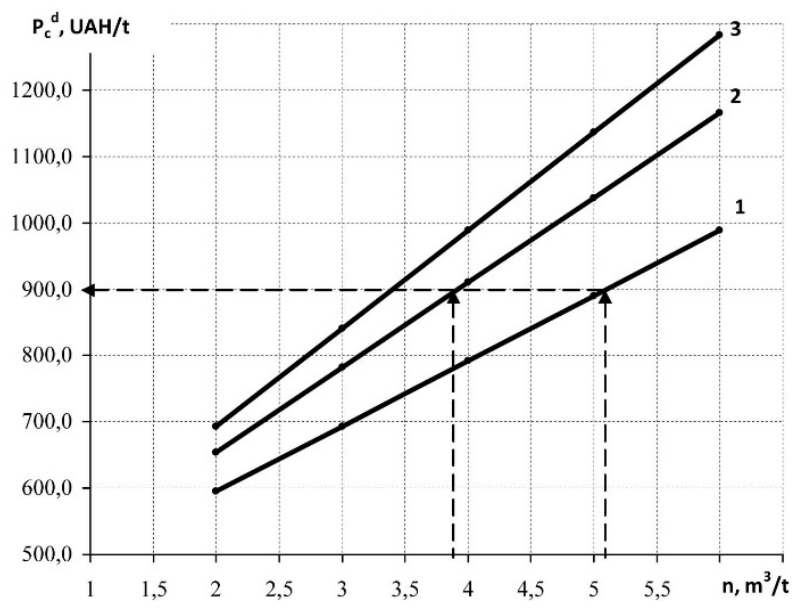

Fig. 2. Changes in the price of the concentrate of the Northern mining and processing plant, depending on the current overburden ratio when the iron content of the concentrate in the world market 66\%: 1 - at the rate of the profit $\psi=0 \% ; 2-$ when $\psi=30$; $3-$ when $\psi=50$.

Thus, with the increase of the overburden ratio and with the increase of the profitability of the enterprise, the price of production of the designed enterprise will increase. There will come a time when the price of production will rise to the limit value $P_{c}^{W}$. Then, substituting in the condition of competitiveness of marketable product of the designed pit (1), the value of its possible price, we obtain:

$$
\frac{\beta^{d} \cdot\left(a_{m}^{d}+a_{c}^{d}+b^{d} \cdot n_{c . o .}\right) \cdot(1+\psi)}{\gamma_{c}^{d} \cdot \beta^{W}} \leq P_{c}^{W} .
$$

Based on this inequality, the cut-off overburden ratio is defined as: 


$$
n_{c . o .}=\frac{\frac{P_{c}^{W} \cdot \gamma_{c}^{d} \cdot \beta^{W}}{\beta^{d} \cdot(1+\psi)}-\left(a_{m}^{d}+a_{c}^{d}\right)}{b^{d}} .
$$

In the table 1 we report the present value of the concentrate of the Northern mining and processing plant calculated by the formula 6 .

Table 1. The price of concentrate on the world market and the price of the concentrate of the Northern mining and processing plant depending from the iron content.

\begin{tabular}{|c|c|c|}
\hline \multirow{2}{*}{$\begin{array}{c}\text { Iron content in the } \\
\text { concentrate, \% }\end{array}$} & \multicolumn{2}{|c|}{$\begin{array}{c}\text { The price of the concentrate, } \\
\text { UAH/t }\end{array}$} \\
\cline { 2 - 3 } & $\begin{array}{c}\text { In the world } \\
\text { market }\end{array}$ & $\begin{array}{c}\text { Discounted } \\
\text { value } \\
\text { Northern MPP }\end{array}$ \\
\hline 62 & 1086,4 & 1150,2 \\
\hline 63 & 1127,0 & 1174,2 \\
\hline 64 & 1167,2 & 1197,1 \\
\hline 65 & 1208,0 & 1219,9 \\
\hline 66 & 1248,0 & 1241,2 \\
\hline
\end{tabular}

Substituting the value of economic and technological indicators of the Northern mining and processing plant in expression (8), we determine the cut-off overburden ratio with different values of profitability (profit rate: $1-0 \%$; $2-10 \% ; 3-20 \% ; 4-30 \% ; 5-40 \% ; 6-50 \%)$. This is shown in Fig. 3. The points in the Fig. 3 correspond to the iron content of the concentrate on the world market.

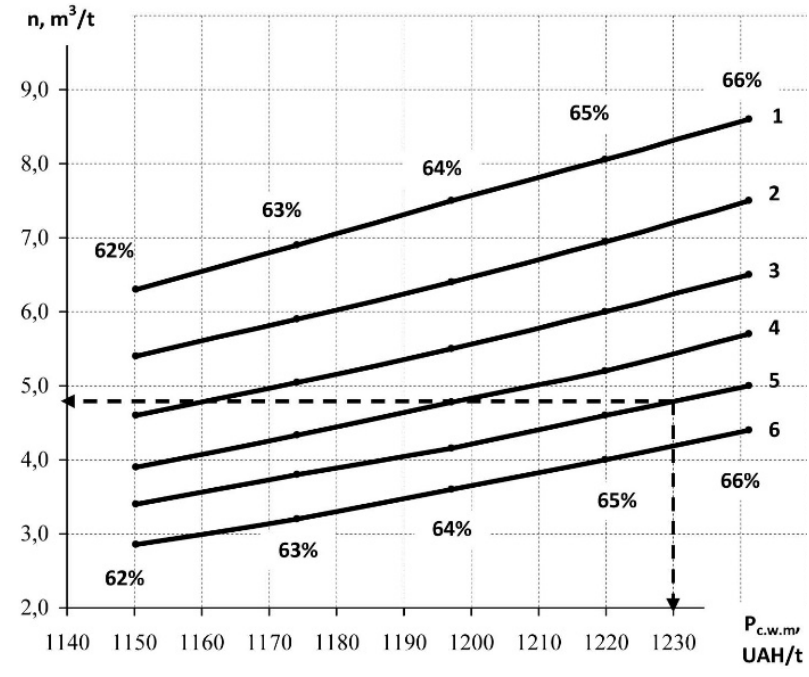

Fig. 3. The dependence of the cut-off overburden ratio on the price of concentrate in the world market: $1-$ at the profit rate $\psi$ $=0 \% ; 2-$ with $\psi=10 \% ; 3-$ with $\psi=20 \% ; 4-$ with $\psi=30 \%$; $5-$ with $\psi=40 \%$; 6 - with $\psi=50 \%$.

In Fig. 4 we present the dependence of overburden ratio from the profit rate for the working conditions of the Pershotravnevij open pit of the Northern MPP.

For example, it is necessary to find out what the price of a concentrate with an iron content of $65.5 \%$ at a rate of $40 \%$ will be. To do this, on the curve with the required norm of the profit (curve 5, Fig. 3) we find a given value of iron content. From the value of the desired iron content (between the group of vertical points $65 \%$ and $66 \%$ ), lower the perpendicular (dashed lines, Fig. 3) on the yaxis and abscissa and determine the values of the overburden ratio and the concentrate price. That is, with an iron content of $65.5 \%$ and a profit rate of $40 \%$, the overburden ratio will be $4.8 \mathrm{~m}^{3} / \mathrm{t}$, and the price of concentrate $-1228 \mathrm{UAH} / \mathrm{t}$.

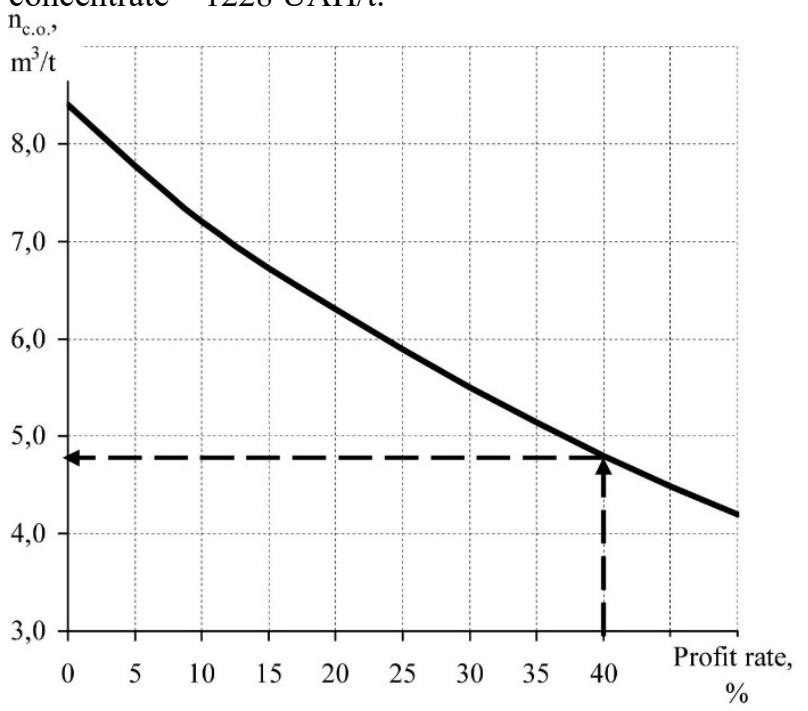

Fig. 4. The dependence of the cut off overburden ratio on the profit rate for the working conditions of the Pershotravnevij open pit of the Northern mining and processing plant.

Studies on theoretical open pits and powerful iron ore open pits of Kryvbas have shown that the accuracy in determining of the open pit boundaries that do not take into account market conditions is up to $50 \%$. Thus, it was determined that in order to more accurately determine the open pit boundaries, it is not necessary to take into account the levels of competition, supply and demand. However, in light of the fact, that it is difficult to predict economic indicators with a high degree of accuracy, it is necessary to move from difficult-to-predicted economic indicators to more stable technological ones when determining the pit outline.

Such technological indicators may serve changes of the ore volumes and overburdens in open pitscompetitions.

In this regard, before designing it is important to carry out analytical work, to make forecasts about the future conditions of competition and demand, as well as changes in price trends and cost of marketable product. At the design stage, it is important to work out the most likely scenarios, and the economic effectiveness of the variants of the final pit boundaries must be determined taking into account the risks of the probably change in the market conditions.

\section{Conclusions}

A new method of determination of the cut-off overburden ratio has been developed, that allows the determining while the world market price of iron ore products to determine the open pit boundaries, which ensure the competitiveness of mining and processing plant. According to the developed method, the values of the cut off overburden ratio for the Pershotravnevij open pit of the Northern mining and processing plant were determined, which ensure the competitiveness of iron ore 
marketable product in the world market at different values of the profit rate. Thus, this principle of defining the boundaries of opencast mining takes into account the dynamics of the external competitive environment of the mining enterprise.

\section{References}

1. Opredelenie perspektivnyh granic Annovskogo karera OAO "SevGOK", Otchet o NIR (Gosudarstvennoe predpriyatie "Nauchno issledovatelskij gornorudnyj institute", Krivoy Rog, 2010).

2. Opredelenie perspektivnyh granic $i$ proizvoditelnosti Pervomajskogo karera PAO "SevGOK”, Otchet o NIR (Akademiya gornyh nauk Ukrainy, Krivoy Rog, 2014)

3. Opredelenie perspektivnyh granic karera, obespechivayushih konkurentosposobnost zhelezorudnoj produkcii Poltavskogo GOKa, Otchet o NIR (Gosudarstvennoe vysshee uchebnoe zavedenie "Krivorozhskij nacionalnyj universitet", Krivoy Rog, 2014).

4. A.I. Arsentev, Opredelenie proizvoditelnosti i granic karerov, 2nd edn. (Nedra, Moscow, 1970), pp. 175198.

5. A.I. Arsentev, A.K. Polishuk, Razvitie metodov opredeleniya granic karerov (Nauka, Leningrad, 1967), pp. 68-82

6. V.V. Rzhevskij, Otkrytye gornye raboty (Nedra, Moscow, 1985), pp. 256-263

7. B.P. Yumatov, Gornyy zhurnal 2, 45-53 (1962)

8. V.S. Hohryakov, Proektirovanie karerov (Nedra, Moscow, 1980), pp. 115-128

9. A.I. Arsentev, Konechnyie granitsyi karerov (Publishing Sankt-Peterburgskiy Gornyiy institute, Sankt-Peterburg, 1995), pp. 29-41

10. V.G. Bliznyukov, Opredelenie glavnyh parametrov karera s uchetom kachestva rudy (Nedra, Moscow, 1978), pp. 105-118

11. V.G. Bliznyukov, I.V. Baranov, Visnik Kryvorizkoho tekhnichnoho universytetu 18, 7-11 (2007)

12. Yu.I. Anistratov, K.Yu. Anistratov, Proektirovanie karerov (NPK “Gemos Limited”, Moscow, 2002), pp. 111-127

13. Opredelenie perspektivnyh granic i proizvoditelnosti karera Inguleckogo gorno-obogatitelnogo kombinata, Otchet o NIR (Gosudarstvennoe predpriyatie "Nauchno issledovatelskij gornorudnyj institute", Krivoy Rog, 2007)

14. V.G. Bliznyukov, S.A. Lucenko, Scientific bulletin of National Mining University 1(157), 44-49 (2017)

15. V.G. Bliznyukov, I.V. Baranov, A.V. Savickij, Visnik Krivorizkogo nacionalnogo universitetu 31, 3-6 (2012)
16. A. Selyukov, R. Rybár. Calculation of Boundary Stripping Ratio Errors at the Stage of Quarries Designing. E3S Web of Conferences (2019). doi:10.1051/e3sconf/201910501043

17. V. Kalyuzhin, F. Karavaytsyev, V. Shchukina, Determination of the limits of municipal formations in the inhomogeneous geoinformation space. E3S Web of Conferences (2019). doi:10.1051/e3sconf/201911002117

18. S. Moldabayev, B. Rysbaiuly, Zh. Sultanbekova, N. Sarybayev, Methodological approach to creation of the $3 \mathrm{D}$ model of an oval-shaped open pit mine. E3S Web of Conferences (2019). doi:10.1051/e3sconf/201912301049

19. V. Mikhalchenko, The Concept of Resource Use Efficiency as a Theoretical Basis for Promising Coal Mining Technologies. E3S Web of Conferences (2017). doi:10.1051/e3sconf/20172104007

20. S.A. Lutsenko, V.G. Bliznyukov, Quality - Access to Success 18 (S1), 226-230 (2017) 